\title{
探讨城市规划设计中的生态城市规划
}

胡永军

天尚设计集团有限公司，浙江 杭州 310000

[摘要]文章将立足现代城市, 探讨城市规划设计存在的不足之处、城市规划设计的原则和具体路径, 以期为有识之士提供参 考，不断提高我国城市的规划设计水平，打造生态城市、绿色城市。 [关键词]城市规划; 规划设计; 生态城市

DOI: $10.33142 /$ ec.v2i7.492

中图分类号：TU984.115

文献标识码：A

\section{Discussion on Ecological City Planning in Urban Planning and Design}

HU Yongjun

Tianshan Design Group Co., Ltd., Zhejiang Hangzhou, 310000 China

\begin{abstract}
Based on the modern city, this paper discusses the shortcomings of urban planning and design, the principles and specific paths of urban planning and design, in order to provide reference for people of insight, constantly improve the planning and design level of cities in China, and build ecological cities and green cities.
\end{abstract}

Keywords: Urban planning; Planning and design; Ecological city

\section{引言}

我国的经济社会不断发展，城市规模日益扩大。在城市规模日益扩大的背景下，人们更加关注城市规划。城市建 设关乎城市居民的发展, 以及城市形象的塑造。为了彰显城市特色, 凸显城市鬼力, 应该将着眼点放在城市规划设计 上, 实现生态城市创设目标。

\section{1 当下生态城市规划存在的不足之处}

\section{1 布局并不合理}

我国幅员辽阔，城市规划存在差异。城市经济发展水平不同，生态建设情况也不尽相同。当前很多城市在规划过 程中存在问题, 阻碍了城市的可持续发展。为了优化城市生态环境, 需要从生态层面考量, 扩展城市的绿地面积。对 我国城市进行分析，发现很多城市都没有形成合理布局，市内绿地面积少之又少，且分布并不集中。我国城市绿地大 多以点状形式存在，片状绿地规模很小。在绿地组成中，草坪占据的比例最大，灌木等绿色植物明显不足。由于绿地 面积较小，城市生态建设效率相对较低 ${ }^{[1]}$ 。

\section{2 绿色植物单一}

我国城市在规划建设过程中，会对生态空间进行分割，根据物种类型进行区域划分。很多城市将同一物种的绿色 植物孤立起来, 阻碍了绿色植物与其他植物的相通, 群落分层无法实现, 生物多样性无法得到保证。一些区域乔木集 中、一些区域灌木集中，两种或两种以上绿色植物的混合搭配比较少见，导致城市绿化乏善可陈。绿色植物种类较少， 不仅会影响城市的绿化效果，还会影响城市的整体形象。

\section{3 缺乏科学导向}

生态城市在我国出现较晚，生态城市规划设计并未形成体系，在实践过程中，很容易遇到技术性和理论上的问题。 城市规划设计的难度较大, 设计者不仅要对城市空间进行划分, 还需要对土地资源进行优化利用, 不断提高生态设计 水平。城市特点不同, 生态设计方向明显不同, 设计师需要坚持科学导向, 凸显城市的生态特色, 彰显城市的绿色形 象。当前我国城市规划师们并未形成统一的设计理念，对生态城市的理解度不够，导致生态城市规划容易沦为形式化 的产物。

\section{4 规划设计笼统}

生态城市规划设计的最主要目的就是促进城市的可持续发展, 为了实现这一目标, 我国需要借鉴相关经验, 制定 生态城市规划方案, 解决生态城市规划问题。当前我国的 “生态城市” 较少, 在成功案例不足的情况下, 规划设计容 易陷入瓶颈。生态城市规划具有复杂性特征, 需要耗费大量的人力资源、物力资源, 在很长一段时间内, 我国都将处 于探索期。我国需要不断突破技术局限、资金局限、人才局限等，提高生态城市的规划设计质量。 


\section{2 生态城市规划的主要原则}

\section{1 完整性}

生态城市规划并不是对城市的改造，而是对城市的优化。在生态城市规划过程中，设计师应该保证城市生态系统 的完整性, 在已有的生态系统基础上进行创新。设计师需要考察生态系统特征, 适当引入新的物种, 避免对生态系统 造成负面影响, 继续发挥生态系统的功能 ${ }^{[2]}$ 。

\section{2 科学性}

生态城市规划并不是一项简单的工作, 设计师不仅要追求生态效益, 还要追求社会效益、人文效益。在物质生活 日益丰富的今天, 人们的精神需求更加旺盛。人们渴求在绿色城市中生活, 寻求心灵上的栖息之地。设计师应该立足 城市居民的现实需要，对城市开展系统研究，设定科学的生态城市规划方案，提高生态城市规划水平。

\section{3 合理性}

生态城市规划需要秉持合理性原则, 设计师应该分析城市生态系统的特点, 保护生物多样性, 提高城市绿化水平。 以绿色植物的引入为例, 城市需要因地制宜, 根据城市区域特点确定植物类型, 形成不同的生物群落, 整合生态系统 中的各个因子, 为生态城市的构建助力。

\section{4 经济性}

设计者在规划生态城市时, 要把握城市的经济发展情况。生态城市构建应该和经济发展保持一致, 设计者需要构 建生产循环系统, 不断降低能源消耗量, 提高能源的利用效率。在可持续发展战略的导向作用下, 设计师需要对清洁 能源进行开发，打造良好的生态环境；需要对生态环境进行保护，有效防治各类环境污染。

\section{3 生态城市规划的重要路径}

\section{1 制定规划方案}

生态城市规划直接关系着城市的健康发展, 为了提高城市发展水平, 加快城市发展速度, 应该将着眼点放在城市 规划上, 保证城市规划的合理性、科学性。城市建设部门承担着重要的工作责任, 应该充分认识到自己的工作价值, 形成科学的城市规划方案。随着时代的不断发展, 生态城市理论更加成熟, 城市建设部门应该将生态城市作为城市建 设的重要参照点, 并坚持以生态城市建设作为目标。很多城市在制定规划方案时, 仅仅关注了城市的经济效益。针对 这一情况, 应该促进城市经济与城市生态的协调发展, 把生态环境作为城市建设的关键一环。现代城市规划方案必须 含括以下几个内容: 第一, 需要稳定社会秩序, 保证社会的可持续性发展。第二, 需要维持经济运转, 保证城市的经 济效益获取。第三，需要不断优化环境，保证生态系统的正常运行。

\section{2 保证生态量度}

现代城市飞速发展, 可持续理念深入人心。人们对建筑设计提出要求, 设计师需要把握城市建设与生态建设的关 系, 实现二者的互联互通。通过设计实践发现, 城市建设与生态建设可以实现并行: 绿色植物能够拓展建筑物的功能, 提高建筑物的审美效果。在建筑设计中渗透绿色理念, 能够扩展城市绿色景观的面积, 改善城市的局部环境, 缓解环 境污染。从这个角度来看, 绿化设计已经成为城市建设的重要内容, 在规划设计过程中, 应该从绿化角度出发, 充分 认识到绿色建筑的重要性, 并增加绿色建筑的数量。当前我国很多城市都提出了绿化要求, 设计师应该考察城市的绿 化要求, 确定城市的绿色容积率, 并以此为依据开展城市规划设计。同时, 设计师应该设定不同地块的绿化功能, 并 根据发展规划指数，对面积不同的地块进行差异化设计。

\section{3 提高设计精度}

生态城市规划设计考察了设计师的专业能力, 设计师需要不断提升个人的专业设计能力, 制定城市规划设计目标, 提高城市规划设计精度。在制定城市规划方案时, 设计师需要立足城市的生态环境, 分析城市的风格特色, 考察城市 的民俗文化等等。生态城市基础设计应该包括三方面: 第一是城市住宅, 第二是城市产业, 第三是城市景观。在开展 住宅设计时, 可以立足生态建筑学, 对城市住宅结构进行优化, 围绕居民核心需求进行系统设计。在开展产业设计时, 可以立足循环经济, 打造一体化的工业体系, 形成集教育、医疗、文化于一体的产业链条。在开展景观设计时, 可以 立足城市街道、城市园林等等, 对街道园林进行绿化设计。

\section{4 结论}

综上所述, 我国的经济社会不断发展, 城市规模日益扩展。人们对城市发展提出了更高需要, 我国城市需要制定 规划方案, 朝着生态城市的方向迈进。设计师承担着重要的生态城市规划责任, 应该把握生态城市的内涵, 秉持生态 城市的建设原则, 寻找生态城市规划的合理路径。

\section{[参考文献]}

[1]高柳. 当前生态城市规划设计原则及其关键点的探究 [J]. 现代物业 (中旬刊), 2019 (02) : 105 .

[2]王峰. 对于城市规划设计中的生态城市规划研究 [J]. 城市建设理论研究 (电子版), 2017 (16): 23-24.

作者简介: 胡永军 (1984.10-) 浙江杭州, 从事工作方向城市规划。 